\title{
The Customary Voiceless Mother and Dominating Daughter in Indian Women Writings
}

\author{
Shivani Sharma
}

Department of Humanities, University of Rajasthan, India

Received: 3 Jul 2021; Received in revised form: 11 Jul 2021; Accepted: 25 Jul 2021; Available online: 04 Aug 2021 (C)2021 The Author(s). Published by Infogain Publication. This is an open access article under the CC BY license (https://creativecommons.org/licenses/by/4.0/).

\begin{abstract}
The present paper is an attempt to discuss the marginalised voice of "the mother" figures in mainstream women writers of India like Shashi Deshpande, Kiran Desai, and Manju Kapoor belonging to different decades and has significantly projected the dimensions of the mother-daughter relationship. Though in their writings, the mothers are voiceless and marginalised by none other than their daughters. Their projection of voiceless mothers and sole-dominated daughters has become a never-ending custom in Indian literature where mothers are being muted with no perspectives. The discussion is focused on the idealisation of motherhood and voiceless mothers projected as the "bad mother" without listening to them.
\end{abstract}

Keywords—idealisation, marginalisation, mother, motherhood, mute.

\section{INTRODUCTION}

Mother

I write home

I am alone and

Give me my body back.

-Susan Griffin (1976)

With the evolution of humans, the relationship between the mother and her child has been considered the most prestigious and sacred relationship because the mother plays the role of 'nurturer 'by sacrificing her 'self' to raise her child. What is a 'mother 'or 'motherhood'? Motherhood has been described as the institution generated by the dominant male patriarchy which describes it as "essential, normal and natural" for all women (Rhoda K. Unger, 2001). By denying the concept delineated by the patriarchy, the feminists like O'Reilly brings out the concept of 'mothering 'as an experience. Hence, mothering is an experience not confined to biological, cultural and social aspects. A mother's relationship with her child especially with her daughter has been described as very ambivalent and troublesome on which a number of studies have been done.
In a mother-daughter relationship, a mother enacts an important role in creating the concept of self or "I am" for a daughter. In the phase of infancy, a daughter constructs her own identity vis-a-vis her mother and begins questioning who I am. Thus, her sexual identity crisis is resolved by her first object relationship with her mother and the castration complex, not by its biological anatomy (Freud, 1933). Sigmund Freud in his lecture "Femininity" talks about the pre-oedipal phase of a girl in which she understands her mother as her own extension, not the other individual. This phase is all about her attachment with her mother while assuming her father as a rival. Here, she initiates her prime object relationship with her mother. Creating her own 'self 'by observing her mother's body, a daughter looks over her mother's body and immediately identifies herself with her mother.

Though this fancy phase ends as a daughter hits her puberty or reaches to negative oedipal complex or Electra complex (Jung, 1915) where she realises her inability to possess penis (castration-anxiety), a symbol of power and turns towards her father, the symbol of power in society. This results in a hostile attitude of the daughter towards her mother as she finds her mother conventional and subordinate to the power of 
society. In this phase, the daughter defies her mother figure but acquires her identity of 'feminine 'from her mother. By resolving her oedipal phase, a girl enters into her latency period where penis-envy and sexual desires seem feeble. Searching for another substitute for her mother, the daughter finds solace in the company with her peers to crush her pre-puberty identification with her mother and finding her fear of becoming like her own mother. A daughter replaces her mother's love with other heterosexual relationships outside the family (Chodorow, 1978). To be afraid of becoming like her own mother which Lynn Sukenick termed as "matrophobia" emerges as another aspect of psychoanalysis. The terminology "Matrophobia" indicates the internal nature of a daughter who has the fear in her psyche of becoming a mother like her mother. Adrienne Rich in her work explains the term as "the fear not of one's mother or motherhood but of becoming one's mother" (235). After resolving all three phases, a daughter when becomes a mother, remembers her mother and takes her place. Since her birth, she finds her mother falling for the "victimisation 'of the society and doesn't revolt against it and takes in "whatever comes" (243).

Another facet is 'omnipotent mother 'who surpasses her boundaries and possesses the individuality of her own daughter by breaking all boundaries that result in the hostility of a daughter towards her mother. Luce Irigaray in her essay And the One Doesn't Stir Without the Other (1997) postulates her psychoanalysis comprehension of the mother-daughter relationship and especially the effect of an omnipotent mother on her daughter. She posits, "With your milk, Mother, I swallowed ice. And here I am now, my insides frozen" (60). A daughter feels suffocated as she doesn't find her space and finds the presence of her own mother in each aspect of her life. Therefore, to acquire her individuality, she breaks the connections with her mother and goes on an expedition to find herself. Despite all kinds of hostile attitudes towards her mother, a daughter runs towards her own mother. A daughter's desire of possessing her mother emerges in the pre-oedipal phase where she doesn't want to separate herself from her mother. Thus, a moderate desire of identifying herself with her mother is incessantly running in her psyche from the pre-oedipal period to the end.

In contrast, a mother relives her unfulfilled desires in her daughter. When a woman becomes a mother, she relives her experiences with her own mother and identifies with her mother as well as her daughter too. Re(experience) with her child, a mother relives her childhood and consider herself a "cared-for child" (Chodorow, 1978). Chodorow explicitly mentions a woman's transformation into a mother where she experiences her daughter's life as her own and enjoys it. Doing so, she forgets and surpasses the boundaries and turns into an omnipotent mother. While her daughter fights for her individuality, a mother loses her grip and let her daughter go.

After analysing all kinds of theories in psychoanalysis, sociology, feminism, anthropology, etc. delineates the existence of a daughter in the shadow of her mother and her marginalisation by her own mother. These discourses are not only created by male writers but the mainstream female theorists like Nancy Chodorow, Adrienne Rich, Virginia Woolf, Marianne Hirsch, Luce Irigaray, etc. on the world platform projected voiceless mother and talkative-daughters. The concepts of omnipotent mother, good mother-bad mother, negative Oedipus complex are the perspectives of a girl towards her mother. In revert, the mothers are being presented as overlooked figures who are customary voiceless.

In our Indian literature, the mother figures in matrilineal centred writings are either muted or disappeared. If a mother exists in the scenario, she has not been given any perspective. Especially, in India, the role of mother has been comprehended as a goddess, nature, country, etc. In the name of the idealisation of the role of mother, the projection of a woman as a mother has always been of a marginalised woman who doesn't have a voice and follows the path paved by society. Perpetually, the description of this mother-daughter relationship has been uplifted in Indian writings by giving voice to the daughter only and by women writers too. Though, here they ignored the mother and kept lifting daughters.

In Anita Desai's novel Fasting, Feasting, the elder daughter Uma is in the quest for her own space as she finds her mother typically marginalised by the male patriarchy. She calls her mother, "MamaPapa" as she doesn't have any identity of her own and " had ever had separate existences" (5). While her younger brother Arun takes birth, Uma has been denied to go to school, so she can take care of her brother. Thus, her mother's inability to speak against her father and her mother's constant expectations of being a 'conventional 'daughter drifts apart Uma from her mother. She blames her mother for her failures in her life.

In Manju Kapur's Difficult Daughters, Virmati has been portrayed as a daughter who despises her mother's demands and craves the education which she has been denied. She has been taught about her duties as a wife and mother. Although, when Virmati becomes the mother of a daughter named, Ida, she asks her to 'adjust, compromise and adapt'. Therefore, they shared a sour bond due to limitations put on her. On the other hand, Shashi 
Deshpande sets forth the other dimension of a motherdaughter relationship in Small Remedies through the relationship of Bai and her daughter Munni. Bai, a rebellious woman who smashed the patriarchy and builds up her own identity as a famous singer, shares a broken relationship with her own daughter Munni. As Freud implies that in the infantile phase, a child needs her mother around and builds the base for their relationship. Hence, Bai acquires her identity but forgets her role of 'nurturer' for her daughter. This creates ambivalence and discord between the two, and Munni begins to resent her own mother. She resists everything which her mother stands for. Here, the discord between the two emerges not because Bai fails to fulfil her duties and achieves her individuality but for being an unconventional mother for her daughter. Another mother-daughter duo presented by Deshpande in the novel is Leela and Madhu. This duo is unique as it breaks the biological aspect of 'mothering'. Leela is not the biological mother of Madhu but nurtures her as her own mother. Being a motherless child, Madhu is nurtured by her father and Leela. She sets forth that "With Leela in my life, I've never felt the lack of a mother" (2000: 151). Leela inspires Madhu and advises her.

To summarise, the discourses created by psychoanalysts are in favour of a daughter.

In Indian writings, mothers have been defied as a goddess who is famously known for her self-sacrifice. If a mother ditches conventional motherhood then the negative outcomes have been portrayed by the writers. Thus, "the mother" figures are idealised and asked to follow the path set by society. Even though, in a mother-daughter relationship, the writers hold the mother blame for the daughter's struggle and dilemma. Hence, the marginalised character of the mother is projected as helpless, subjugated by the patriarchy and her daughter's expectations. Therefore, except the society, a mother is marginalised by none other than her own daughter.

\section{REFERENCES}

[1] Chodorow, N. (1978). The Reproduction of Mothering: Psychoanalysis and the Sociology of Gender. Berkeley, CA: University of California Press..

[2] Desai, Anita (2000). Fasting, Feasting. London, Vintage.

[3] Deshpande, Shashi (2004) Sweet Remedies. New Delhi, Penguin India Publishers.

[4] Freud, Sigmund (1960).“ Femininity.” In James Strachey and Anna Freud (Ed.) New Introductory Lectures on Psycho-Analysis and Other Works (vol. 22, pp. 112135).

[5] Griffin, Susan (1976). "Mother and Child" Like the Iris of an Eye. New York, Harper and Row.
[6] Irigaray, Luce (1981).“ And the One Doesn't Stir Without the Other." Journal of Women in Culture and Society (vol.7, no.1). Retrieved from https://www.journals.uchicago.edu/doi/10.1086/493859

[7] Jung, C. G. (1915). The Theory of Psychoanalysis. Journal of nervous and mental disease. Publishing Company,

[8] Kapur, Manju (1999). Difficult Daughters. London, Faber and Faber.

[9] O'Reilly, Andrea (2004). From Motherhood to Mothering: The Legacy of Adrienne Rich's Of Woman Born. Albany: State University of New York Press.

[10] Sukenick, Lynn (1973). 'Feeling and Reason in Doris Lessing's Fiction." Contemporary Literature (pp. 51535). Retrieved from doi: 10.2307/1207470.

[11] Unger, Rhoda K. (2001). Handbook of the Psychology of Women and Gender, print, John Wiley \& Sons. 